\title{
FAKTOR YANG BERHUBUNGAN DENGAN KEPATUHAN PERAWAT DALAM MELAKUKAN 6 LANGKAH CUCI TANGAN
}

\author{
Fatma Jama, Yuliana \\ Fakultas Kesehatan Masyarakat \\ Universitas Muslim Indonesia
}

\begin{abstract}
ABSTRAK
Kepatuhan merupakan masalah besar yang dihadapi rumah sakit dan masih cukup tinggi terjadi di Indonesia.Kegagalan dalam menjaga kebersihan tangan dengan baik dan benar merupakan penyebab utama infeksi nosokomial. Perawat sebagai tenaga kesehatan yang paling banyak berinteraksi dengan pasien harus patuh dalam melakukan praktik 6 langkah cuci tangan. Penelitian ini bertujuan untuk mengetahui faktor yang berhubungan dengan kepatuhan perawat dalam melakukan 6 langkah cuci tangan di ruang Bedah dan Interna RSUD Labuang Baji Makassar. Desain Penelitian ini adalah cross sectional study dengan teknik pengambilan sampel total sampling. Responden penelitian berjumlah 41 responden. Analisis yang digunakan analisis chi square dengan tingkat kemaknaan $a<0,05$. Hasil penelitian menunjukkan ada hubungan antara motivasi dengan kepatuhan dalam melakukan 6 langkah cuci tangan ( $p=v a l u e 0,04)$, tidak ada hubungan antara fasilitas dengan kepatuhan dalam melakukan 6 langkah cuci tangan ( $p=v a l u e$ 0,564), dan tidak ada hubungan antara supervisi kepala ruangan dengan kepatuhan dalam melakukan 6 langkah cuci tangan ( $p=$ value 0,229). Kesimpulan dari penelitian ini adalah ada hubungan motivasi dengan kepatuhan dalam melakukan 6 langkah cuci tangan, tidak ada hubungan antara fasilitas dengan kepatuhan dalam melakukan 6 langkah cuci tangan, dan tidak ada hubungan antara supervisi kepala ruangan dengan kepatuhan dalam melakukan 6 langkah cuci tangan. Di harapkan adanya suatu program pendidikan tentang 6 langkah cuci tangan dan persamaan persepsi terhadap pentingnya 6 langkah cuci tangan yang dapat mengurangi infeksi nosokomial di RSUD Labuang Baji Makassar.
\end{abstract}

Kata kunci : Kepatuhan Cuci Tangan, Motivasi, Fasilitas, Supervisi

\begin{abstract}
Compliance is a major problem faced by hospitals and is still quite high in Indonesia. Failure to maintain good and proper hand hygiene is a major cause of nosocomial infections. Nurses as health workers who interact the most with patients must be obedient in practicing the 6 steps of hand washing. This study aims to determine the factors associated with nurse compliance in performing the 6 steps of hand washing in the Surgical and Internal Room of Labuang Baji Hospital Makassar. The design of this study was a cross sectional study with a total sampling technique. Research respondents numbered 41 respondents. The analysis used chi square analysis with significance level $a<0.05$. The results showed there was a relationship between motivation and compliance in doing the 6 steps of washing hands $(p=$ value 0.04$)$, there was no relationship between facilities with compliance in doing the 6 steps of washing hands $(p=$ value of 0.564$)$, and there was no relationship between supervision the head of the room with adherence to the 6 steps of hand washing ( $p=$ value 0.229). The conclusion of this study is there is a relationship of motivation with compliance in doing the 6 steps of washing hands, there is no relationship between facilities with compliance in doing the 6 steps of washing hands, and there is no relationship between supervision of the head of the room with compliance in doing the 6 steps of washing hands. It is expected that an educational program on the 6 steps of hand washing and equality of perception of the importance of the 6 steps of hand washing can reduce nosocomial infections in RSUD Labuang Baji Makassar.
\end{abstract}

Keywords: Hand Washing Compliance, Motivation, Facilities, Supervision 
Alamat korespondensi: Jl.Urip Sumoharjo KM.5 Program Studi Ilmu Keperawatan Universitas Muslim Indonesia, Makassar, Sulawesi Selatan

Email: fatma.jama@umi.ac.id

\section{PENDAHULUAN}

Survey yang dilakukan WHO di 55 rumah sakit dari 14 negara dikawasan Eropa, Timur Tengah, Asia Tenggara dan Pasifik Barat, ditemukan sebanyak 8,7 \% kejadian infeksi nosokomial dan $10 \%$ kejadian infeksi nosokomial di temukan di Asia Tenggara. WHO menyatakan bahwa pada 7 juta orang yang terkena infeksi nosokomial, terdapat peningkatan biaya perawatan sebesar 80 milyar dolar Amerika. Central of Disease Control (CDC) memperkirakan biaya yang dikeluarkan rumah sakit meningkat menjadi 208\% dikarenakan infeksi tersebut (WHO, 2016).

Menurut penelitian yang dilakukan oleh Karuru (2016) di RSUP Prof. Dr. R. D. Kandou Manado, didapatkan data tingkat kepatuhan tenaga kesehatan dalam melakukan 6 langkah cuci tangan sebesar 5,2\% dan tidak patuh sebanyak 94,8\%, sedangkan untuk perawat sendiri tingkat kepatuhan dalam melakukan 6 langkah cuci tangan hanya sebesar 6,6\%. Enam langkah cuci tangan adalah suatu upaya mencegah infeksi yang ditularkan melalui tangan dengan menghilangkan kotoran dan debris serta menghambat atau membunuh mikroorganisme pada kulit yang dapat diperoleh dari kontak antara pasien dengan lingkungan. Tangan yang terkontaminasi merupakan penyebab utama perpindahan. Kegagalan untuk melakukan kebersihan tangan dengan baik dan benar merupakan penyebab utama Infeksi nosokomial dan penyebaran mikroorganisme multiresisten di fasilitas pelayanan kesehatan (Rodyah, 2015).

Kepatuhan perawat dalam melakukan 6 langkah cuci tangan sangat penting dilakukan karena ketidakpatuhan dapat menimbulkan dampak antara lain : (1) Bagi pasien, penambahan diagnosa penyakit dan memperpanjang jumlah hari rawat selama di rumah sakit hingga dapat menyebabkan kematian; (2) Bagi pengunjung, dapat menularkan kepada orang lain setelah meninggalkan rumah sakit; (3) Bagi perawat, akan menjadi barier (pembawa kuman) yang menularkan kepada pasien lain dan diri sendiri; (4) Bagi rumah sakit, menurunkan mutu pelayanan rumah sakit hingga pencabutan ijin operasional rumah sakit. Motivasi juga mempengaruhi perawat dalam melaksanakan asuhan keperawatan yang sesuai dengan standar prosedur RSUD Labuang Baji Makassar. Perawat yang mempunyai motivasi yang tinggi, muncul suatu keinginan untuk memenuhi kebutuhan penerapan 6 langkah cuci tangan Dalam penerapan cuci tangan, supervisi juga di sini salah satu faktor yang dapat memengaruhi kepatuhan perawat. Perawat yang mendapatkan supervisi cenderung patuh dibandingkan perawat yang tidak mendapatkan supervisi. Supervisi bagian dari fungsi directing (pergerakan/pengarahan) dalam fungsi manajemen yang berperan mempertahankan agar segala kegiatan yang telah diprogramkan dapat dilaksanakan dengan benar dan lancar. Dan fasilitas juga sangat mempengaruhi karena ketersediaan fasilitas yang kurang memadai membuat perawat sulit untuk melakukan 6 langkah cuci tangan.

Observasi awal yang dilakukan dengan mengambil hanya 3 ruangan diantaranya ruang Interna yaitu ruangan Baji Mamminasa berjumlah 14 perawat, Baji Pammai 13 perawat, dan ruang Bedah Baji Kamase berjumlah 14 perawat. Sehingga ke 3 Ruang tersebut Bedah dan Interna RSUD Labuang Baji Makassar berjumlah 41 orang.

Hasil observasi peneliti lakukan di ruang Bedah dan Interna RSUD Labuang Baji Makassar tanggal 19 Maret sampai dengan 4 Mei 2019 dengan melakukan observasi terhadap 10 perawat pelaksana saat melakukan 6 langkah cuci tangan didapat 7 perawat yang tidak melakukan 6 langkah cuci tangan dan 3 perawat yang melakukan 6 langkah cuci tangan.

Hasil wawancara yang dilakukan peneliti kepada salah satu perawat pelaksana mengatakan bahwa kadang-kadang mencuci tangan menggunakan westafel tetapi kebanyakan perawat lebih memakai handrub. Jenis cuci tangan yang di ruang Bedah dan Interna adalah handrub dan westafel. Fasilitas yang ada di ruang Interna yaitu terdapat 2 cuci tangan air mengalir (westafel) dan di ruang Bedah 1 westafel. Handrub terdapat 7 di ruang Interna dan terdapat 5 handrub di ruang 
Bedah. Berdasarkan data tersebut maka peneliti tertarik untuk mengetahui "Faktor yang berhubungan dengan kepatuhan perawat dalam melakukan 6 langkah cuci tangan di ruang Bedah dan Interna RSUD Labuang Baji Makassar".

\section{METODE}

Desain yang digunakan dalam penelitian ini adalah analitik observasional menggunakan pendekatan kuantitatif dengan metode cross sectional study. Penelitian ini dilaksanakan pada bulan April-Agustus 2019. Sampel pada penelitian ini adalah perawat yang bekerja di ruang Bedah dan Interna RSUD Labuang Baji Makassar. Teknik pengambilan sampel yang digunakan adalah Total Sampling. Instrumen dalam penelitian ini berupa kuesioner yang akan diberikan kepada perawat dengan menggunakan lembar kuesioner dan observasi dalam bentuk pernyataan. Variabel-variabel

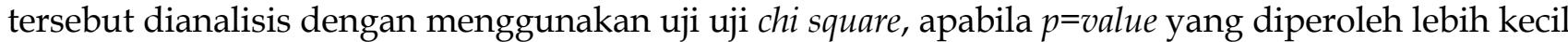
dibandingkan dengan $\mathrm{p}<\mathrm{a}=0,05$, maka Ho ditolak. Apabila $p=v a l u e$ yang diperoleh lebih besar dibandingkan dengan $\mathrm{p}>\mathrm{a}=0,05$, maka Ho gagal ditolak atau Ha diterima.

\section{HASIL DAN PEMBAHASAN}

1. Karakteristik responden

a. Umur

Tabel 1

Distribusi Frekuensi Responden Berdasarkan Umur di RSUD Labuang Baji Makassar

\begin{tabular}{ccc}
\hline Umur & $\mathrm{n}$ & $\%$ \\
\hline $17-25$ & 4 & 9,8 \\
$26-35$ & 11 & 26,8 \\
$36-45$ & 23 & 56,1 \\
$46-55$ & 3 & 7,3 \\
\hline Total & 41 & 100,0
\end{tabular}

Berdasarkan tabel 1 d.apat diketahui bahwa sebagian besar responden berusia 36-45 tahun (dewasa akhir) yaitu sebesar 56,1\% dan sebagian kecil responden berusia 46-55 tahun (lansia awal) yaitu sebesar 7,3\%.

b. Jenis Kelamin

Tabel .2

Distribusi Frekuensi Responden Berdasarkan Jenis Kelamin Di RSUD Labuang Baji Makassar

\begin{tabular}{ccc}
\hline Jenis Kelamin & $\mathrm{n}$ & $\%$ \\
\hline Laki-Laki & 2 & 4,9 \\
Perempuan & 39 & 95,1 \\
\hline Total & 41 & 100,0 \\
\hline
\end{tabular}

Berdasarkan tabel .2 dapat diketahui bahwa sebagian besar responden berjenis kelamin perempuan yaitu sebesar $95,1 \%$. 
c. Pendidikan Terakhir

Tabel .3

Distribusi Frekuensi Responden Berdasarkan

PendidikanTerakhir Di RSUD Labuang

Baji Makassar

\begin{tabular}{ccc}
\hline PendidikanTerakhir & $\mathrm{n}$ & $\%$ \\
\hline D3 & 9 & 22,0 \\
S1 & 20 & 48,8 \\
Ners & 12 & 29,3 \\
\hline Total & 41 & 100,0
\end{tabular}

Sumber :Data primer 2019

Berdasarkan tabel.3 dapat diketahui bahwa sebagian besar tingkat pendidikan terakhir responden lulusan S1 yaitu sebesar 48,8\% dan sebagian kecil lulusan D3 yaitu sebesar 22,0\%.

d. Lama Kerja

Tabel.4

Distribusi Frekuensi Responden Berdasarkan Lama Kerja Di RSUD Labuang Baji

\begin{tabular}{ccc} 
& \multicolumn{2}{c}{ Makassar } \\
\hline Lama kerja & $\mathrm{n}$ & $\%$ \\
\hline Baru & 11 & 26,8 \\
Lama & 30 & 73,2 \\
\hline Total & 41 & 100,0
\end{tabular}

Berdasarkan tabel 5.4 dapat diketahui bahwa sebagian besar responden lama kerjanya yaitu terbilang lama lebih dari 5 tahun mencapai $73,2 \%$ dan yang baru sebanyak $26,8 \%$.

e. Pernah Mengikuti pelatihan PPI (pencegahan dan pengendalian infeksi)

Tabel.5

Distribusi Frekuensi Responden Berdasarkan Pernah Mengikuti pelatihan PPI Di RSUD Labuang Baji Makassar

\begin{tabular}{ccc}
\hline Pernah Mengikuti Pelatihan PPI & N & $\%$ \\
\hline Ya & 16 & 39,0 \\
Tidak & 25 & 61,0 \\
\hline Total & 41 & 100,0
\end{tabular}

Berdasarkan tabel .5 dapat diketahui bahwa sebagian besar responden tidak pernah mengikuti pelatihan PPI yaitu sebesar 61,0\% dan sebagian kecil responden pernah mengikuti pelatihan PPI yaitu sebesar 39,0\%. 
2. Analisis Univariat

a. Motivasi

Tabel .6

Distribusi Frekuensi Berdasarkan Motivasi Responden Dalam Melakukan 6 Langkah Cuci TanganDi RSUD Labuang Baji Makassar

\begin{tabular}{ccc}
\hline Motivasi & $\mathrm{n}$ & $\%$ \\
\hline Termotivasi & 37 & 90,2 \\
Kurang termotivasi & 4 & 9,8 \\
\hline Total & 41 & 100,0
\end{tabular}

Berdasarkan tabel.6 dapat diketahui bahwa sebagian besar responden termotivasi dalam melakukan 6 langkah cuci tangan yaitu sebesar 90,2\% dan sebagian kecil kurang termotivasi yaitu sebesar $9,8 \%$

b. Fasilitas

Tabel .7

Distribusi Frekuensi Berdasarkan Fasilitas Responden Dalam Melakukan 6 Langkah Cuci Tangan Di RSUD Labuang Baji Makassar

\begin{tabular}{ccc}
\hline Fasilitas & $\mathrm{N}$ & $\%$ \\
\hline Tersedia & 27 & 65,9 \\
Tidak Tersedia & 14 & 34,1 \\
\hline Total & 41 & 100,0
\end{tabular}

Berdasarkan tabel .7 dapat diketahui bahwa sebagian besar responden Fasilitas tersedia dalam melakukan 6 langkah cuci tangan yaitu sebesar 65,9\% dan sebagian kecil fasilitas tidak tersedia yaitu sebesar 34,1\%

c. Supervisi Kepala Ruangan

Tabel.8

Distribusi Frekuensi Berdasarkan Supervisi KepalaRuangan Responden Dalam Melakukan 6 LangkahCuci Tangan Di RSUD Labuang Baji Makassar

\begin{tabular}{ccc}
\hline Supervisi Kepala Ruangan & $\mathrm{n}$ & $\%$ \\
\hline Dilakukan & 32 & 78,0 \\
Tidak Dilakukan & 9 & 22,0 \\
\hline Total & 41 & 100,0
\end{tabular}

Berdasarkan tabel .8 dapat diketahui bahwa sebagian besar responden Supervisi kepala ruangan dilakukan dalam melakukan 6 langkah cuci tangan yaitu sebesar 78,0\% dan sebagian kecil Supervisi kepala ruangan tidak dilakukan yaitu sebesar 22,0\%. 
d. Kepatuhan

\author{
Tabel.9
}

Distribusi Frekuensi Berdasarkan Kepatuhan Responden Dalam Melakukan 6 Langkah Cuci Tangan Di RSUD Labuang Baji Makassar

\begin{tabular}{ccc}
\hline Kepatuhan & $\mathrm{n}$ & $\%$ \\
\hline Patuh & 36 & 87,8 \\
Kurang Patuh & 5 & 12,2 \\
\hline Total & 41 & 100,0
\end{tabular}

Berdasarkan tabel 5.9 dapat diketahui bahwa sebagian besar responden patuh dalam melakukan 6 langkah cuci tangan yaitu sebesar 87,8\% dan sebagian kecil kurang patuh yaitu sebesar $12,2 \%$.

3. Analisis Bivariat

a. Hubungan motivasi dengan kepatuhan perawat dalam melakukan 6 langkah cuci tangan

$$
\text { Tabel .10 }
$$

Hubungan Antara Motivasi Dengan Kepatuhan Perawat Dalam Melakukan 6 Langkah Cuci Tangan Di RSUD Labuang Baji Makassar

\begin{tabular}{|c|c|c|c|c|c|c|c|}
\hline \multirow{3}{*}{ Motivasi } & \multicolumn{4}{|c|}{ Kepatuhan } & \multirow{2}{*}{\multicolumn{2}{|c|}{ Total }} & \multirow{3}{*}{$\rho$-Value } \\
\hline & \multicolumn{2}{|c|}{ Patuh } & \multicolumn{2}{|c|}{ Kurang Patuh } & & & \\
\hline & $\mathrm{n}$ & $\%$ & $\mathrm{n}$ & $\%$ & $\mathrm{n}$ & $\%$ & \\
\hline Termotivasi & 35 & 94,6 & 2 & 5,4 & 37 & 100 & \\
\hline Kurang termotivasi & 1 & 25,0 & 3 & 75,0 & 4 & 100 & 0,004 \\
\hline Total & 36 & 87,8 & 5 & 12,5 & 41 & 100 & \\
\hline
\end{tabular}

Berdasarkan tabel .10 diketahui bahwa proporsi responden yang motivasinya termotivasi cenderung patuh dalam melakukan 6 langkah cuci tangan yaitu sebesar 94,6\% lebih kecil jika dibandingkan dengan responden yang motivasinya kurang termotivasi yaitu sebesar 25,0\%. Hasil uji statistik (chi square) didapatkan nilai $\rho=$ Value sebesar $0,04<a=0,05$ yang artinya ada hubungan yang bermakna antara motivasi dengan kepatuhan perawat dalam melakukan 6 langkah cuci tangan.

b. Hubungan antara fasilitas dengan kepatuhan perawat dalam malakukan 6 langkah cuci tangan

Tabel .11

Hubungan Antara Fasilitas Dengan Kepatuhan Perawat Dalam Melakukan 6 Langkah Cuci Tangan Di RSUD Labuang Baji Makassar

\begin{tabular}{llllllll}
\hline \multirow{2}{*}{ Fasilitas } & \multicolumn{4}{c}{ Kepatuhan } & & \\
\cline { 2 - 4 } & \multicolumn{2}{c}{ Patuh } & kurang patuh & Total & $\rho$-Value \\
\hline & $\mathrm{n}$ & $\%$ & $\mathrm{n}$ & $\%$ & $\mathrm{n}$ & $\%$ \\
\hline
\end{tabular}




\begin{tabular}{cccccccc} 
Tersedia & 24 & 88,9 & 3 & 11,1 & 27 & 100 & \\
Tidak tersedia & 12 & 85,7 & 2 & 14,3 & 14 & 100 & 0,564 \\
\hline Total & 36 & 87,8 & 5 & 12,2 & 41 & 100 &
\end{tabular}

Berdasarka

n Tabel .11 diketahui bahwa fasilitas yang tersedia cenderung responden patuh dalam melakukan 6 langkah cuci tangan yaitu sebesar 88,9\% lebih kecil jika dibandingkan dengan fasilitas yang tidak tersedia yaitu sebesar $85,7 \%$. Hasil uji statistik (chi square) didapatkan nilai $\rho=$ Value sebesar $0,564 \leq \mathrm{a}=0,05$ yang artinya tidak ada hubungan yang bermakna antara fasilitas dengan kepatuhan perawat dalam melakukan 6 langkah cuci tangan.

c. Hubungan supervisi ksepala ruangan dengan kepatuhan perawat dalam melakukan 6 langkah cuci tangan

Tabel .12

Hubungan antara Supervisi Kepala Ruangan dengan kepatuhan perawat dalam melakukan 6 langkah cuci tangan di RSUD Labuang Baji Makassar

\begin{tabular}{|c|c|c|c|c|c|c|c|}
\hline \multirow{3}{*}{$\begin{array}{c}\text { Supervisi Kepala } \\
\text { Ruangan }\end{array}$} & \multicolumn{4}{|c|}{ Kepatuhan } & & & \\
\hline & \multicolumn{2}{|c|}{ Patuh } & \multicolumn{2}{|c|}{ Kurang Patuh } & \multicolumn{2}{|c|}{ Total } & \multirow[t]{2}{*}{$\rho$-Value } \\
\hline & $\mathrm{n}$ & $\%$ & $\mathrm{n}$ & $\%$ & $\mathrm{n}$ & $\%$ & \\
\hline Dilakukan & 29 & 90,6 & 3 & 9,4 & 32 & 100 & \\
\hline Tidak dilakukan & 7 & 77,8 & 2 & 22,2 & 9 & 100 & 0,229 \\
\hline Total & 36 & 87,8 & 5 & 12,2 & 41 & 100 & \\
\hline
\end{tabular}

Berdasarkan tabel .12 diketahui bahwa proporsi responden yang supervisi kepala ruangan dilakukan cenderung patuh dalam melakukan 6 langkah cuci tangan yaitu sebesar 90,6\% lebih kecil jika dibandingkan dengan responden yang supurvisi kepala ruangan tidak dilakukan yaitu sebesar $77,8 \%$. Hasil uji statistik (chi square) didapatkan nilai $\rho=v a l u e ~ s e b e s a r$ $0,299>a=0,05$ yang artinya tidak ada hubungan yang bermakna antara supervisi kepala ruangan dengan kepatuhan perawat dalam melakukan 6 langkah cuci tangan.

\section{PEMBAHASAN}

1. Hubungan antara motivasi dengan kepatuhan perawat dalam melakukan 6 langkah cuci tangan di RSUD Labuang Baji Makassar

Motivasi dalam penelitian ini terbagi atas 2 kriteria yaitu termotivasi dan kurang termotivasi. Hasil penelitian dari seluruh sampel perawat yang diteliti yaitu sebanyak 41 perawat di RSUD Labuang Baji Makassar didapatkan bahwa yang termotivasi yaitu sebanyak $94,6 \%$ dan masih terdapat 5,4\% perawat yang termotivasi namun kurang patuh. Hal ini disebabkan oleh usia perawat yang masih masuk dalam usia remaja akhir dan tingkat pendidikan perawat yang hanya D3. Motivasi seseorang berkaitan dengan kebutuhan meliputi tempat dan suasana lingkungan kerja sehingga perawat yang bekerja mengalami penurunan motivasi yang mengakibatkan hasil kerja yang tidak memuaskan dan mengakibatkan tindakan perawat menurun. Beberapa hal ini lah yang membuat perawat masih kurang patuh dalam melakukan 6 langkah cuci tangan. 
Kemudian perawat yang masuk kategori kurang termotivasi namun memiliki kepatuhan sebanyak 25,0\% hal ini dikarenakan lama kerja yang masih tergolong baru merupakan salah satu alasan yang meningkatkan kepatuhan perawat. Perawat yang lama kerja dikategorikan baru ini telah merasa cukup sesuai lama kerja yang dijalani. Adapun saat pengisian kuesioner perawat mengatakan keputusan 6 langkah cuci tangan yang dilakukan adalah kewenangan pribadi masingmasing perawat. Jadi patuh dengan tidak nya seseorang tergantung dari diri sendri.

Asumsi penelitian bahwa semakin termotivasi seseorang melakukan 6 langkah cuci tangan maka semakin tinggi pula tingkat kepatuhannya, pada dasarnya patuh merupakan salah satu cara seseorang dalam melakukan 6 langkah cuci tangan untuk memenuhi motivasi yang diinginkan. Motivasi yang dimiliki oleh perawat maka akan meningkatkan kepatuhan perawat dalam melakukan 6 langkah cuci tangan. Salah satu cara untuk meningkatkan kepatuhan perawat adalah dengan memberikan reward bagi perawat yang melaksanakan kepatuhan perawat dalam melakukan 6 langkah cuci tangan dengan baik dan punishment bagi yang tidak melakukan 6 langkah cuci tangan dengan baik dan benar.

Motivasi merupakan ciri proses spisikolog yang dapat menjelaskan perilaku seseorang berkaitan dengan kepatuhan, kewajiban dan juga kesadaran diri sendiri tanpa ada paksaan dari orang lain. Berdasarkan hasil penelitian diperoleh nilai $\rho=0,04$. Dari hasil penelitian tersebut membuktikan bahwa ada hubungan yang bermakna antara motivasi dengan kepatuhan perawat dalam melakukan 6 langkah cuci tangan di RSUD Labuang Baji Makassar.

Penelitian ini sejalan dengan penelitian (Hutahaean, 2019) yang mengatakan adanya hubungan motivasi dengan kepatuhan perawat dalam Pencegahan dan Pengendalian Infeksi. Hal ini diperkuat dalam (Syamsulastri, 2017) yang menyatakan dalam penelitiannya ada hubungan motivasi dengan kepatuhan perawat dalam praktik hand hygiene DI IGD, ICU DAN IBS RSUD Ade Muhammad Djoen Sintang menunjukkan bahwa ada hubungan yang bermakna antara motivasi dengan kepatuhan perawat dalam melakukan hand hygiene dibuktikan dengan nilai hasil uji statistik didapatkan nilai $\rho$-value 0,07 . Nilai PR 1,890 dengan nilai 95\% CI, artinya proporsi responden yang motivasinya rendah cenderung untuk tidak patuh dalam melakukan hand hygiene 1,890 atau 2 kali lipat lebih besar dibandingkan dengan proporsi responden yang motivasinya tinggi. Hasil ini diperkuat dari hasil analisis sebagian besar motivasi perawat rendah dalam melakukan hand hygiene yaitu sebesar $72,1 \%$. Hasil jawaban beberapa item kuisioner yang diisi responden pada kuisioner diketahui $94,1 \%$ responden mengisi tidak adanya poster tentang hand hygiene membuat responden sering lalai melaksanakan tahapan hand hygiene.

Dari hasil observasi sebagian besar responden memiliki kepatuhan yang tidak patuh dalam melakukan hand hygiene yaitu sebesar 69,1\%. Ketidakpatuhan perawat yang tertinggi adalah tidak melakukan hand hygiene saat tiba di ruangan jaga. Perawat merasa saat tiba diruangan tangan sudah dalam keadan bersih, Selain itu juga tidak ada reward yang diberikan kepada perawat jika melaksanakan kepatuhan hand hygiene dengan baik dan tidak ada punishment bagi yang tidak melakukan hand hygiene dengan baik.

Teori (Samsudin dalam Andriyani) Motivasi merupakan proses mempengaruhi atau mendorong dari luar terhadap seseorang atau kelompok kerja agar mereka mau melaksanakan sesuatu yang telah ditetapkan. Sedangkan menurut Liang Gie dalam Samsudin menyatakan bahwa motivasi adalah pekerjaan yang dilakukan oleh manajer dalam memberikan inspirasi, semangat dan dorongan kepada orang lain, dalam hal ini karyawannya, untuk mengambil tindakan-tindakan tertentu (Andriyani, 2015).

\section{Hubungan antara Fasilitas dengan kepatuhan perawat dalam melakukan 6 langkah cuci tangan di RSUD Labuang Baji Makassar}

Fasilitas dalam penelitian ini terbagi atas 2 kriteria yaitu tersedia dan tidak tersedia. Hasil penelitian dari seluruh sampel perawat yang diteliti yaitu sebanyak 41 perawat di RSUD Labuang Baji Makassar didapatkan bahwa tersedia yaitu sebanyak 88,9\% dan masih terdapat 11,1\% fasilitasnya tersedia namun kurang patuh. Hal ini disebabkan oleh tingkat pendidikan terakhir 
yang hanya D3 dan kurangnya mengikuti pelatihan PPI (pencegahan dan pengendalian infeksi) diketahui sebagian besar responden tidak pernah mengikuti pelatihan, ini yang menyebabkan tingkat pengetahuanya berkurang tentang pentingnya 6 langkah cuci tangan.

Perawat yang masuk kategori fasilitas tidak tersedia namun patuh 85,7\% dan masih terdapat kurang patuh $14,3 \%$ hal ini dikarnakan lama kerja perawat cenderung patuh walaupun fasilitas tidak tersedia perawat hanya mengunakan handrub. Ketersediaan fasilitas diperlukan untuk mendukung terjadinya perilaku patuh. Berdasarkan observasi yang dilakukan peneliti ketersediaan fasilitas seperti westafel masih banyak yang tidak berfungsi namun dalam penelitian ini tidak ada hubungan signifikan. Walaupun dalam penelitian ini tidak ada hubungan, maka ketersediaan fasilitas juga dapat mempengaruhi kepatuhan dalam malakukan 6 langkah cuci tangan. Oleh sebab itu diharapkan rumah sakit untuk lebih memfasilitasi cuci tangan seperti westafel yang tidak berfungsi untuk diperbaiki dan juga lebih meningkatkan pemeliharaan fasilitas sehingga perawat lebih patuh.

Asumsi penelitian bahwa ketersediaan sarana dan prasarana merupakan salah satu faktor yang mendukung individu untuk bekerja. Fasiltas yang tersedia dimasing-masing ruangan seperti alkohol handrub, sabun antimikroba, tissue atau handuk sangat memengaruhi tingkat kepatuhan perawat dalam melakukan 6 langkah cuci tangan. Fasilitas yang baik akan mempengaruhi minat perawat untuk melakukan 6 langkah cuci tangan sehingga perawat sadar dan peduli akan kesehatanya. Berdasarkan hasil penelitian analisa statistik dengan menggunakan uji chi square diperoleh nilai $\rho=0,564$ dimana nilai $\rho$ lebih besar dari $\alpha=0,05$ maka hasil penelitian tersebut membuktikan bahwa tidak ada hubungan antara fasilitas dengan kepatuhan perawat dalam melakukan 6 langkah cuci tangan.

Dalam penyempurnaan pelaksanaan 6 langkah cuci tangan pendekatan multimodal harus dilakukan untuk melengkapi keterbatasan fasilitas lagi guna meningkatkan kepatuhan yaitu kebiasaan dari setiap individu dan suasana dari institusi. Penelitian ini sejalan dengan penelitian (Ivan, 2018) yang menyatakan dalam penelitiannya tidak ada hubungan fasilitas dengan kepatuhan perawat dalam praktik hand hygiene RSUD gunungsitoli. Hasil penelitian menunjukkan bahwa tidak ada hubungan yang bermakna antara Fasilitas dengan kepatuhan perawat dalam melakukan hand hygiene dibuktikan dengan nilai uji statistik (chi square) $\rho=v a l u e ~ 0,663$ Fasilitas yang baik cenderung untuk responden tidak patuh dalam melakukan hand hygiene (82,9\%) dan yang kurang mencapai 17,1\%. Penelitian ini juga sejalan dengan hasil penelitian (Agustanti, 2017) di ruang Bougenvile RSUD Dr. Soedirman Kebumen Tahun 2017 menunujukkan tidak ada hubungan antara fasilitas dengan kepatuhan hand hygiene 5 moment dengan nilai $\rho=v a l u e ~ 0,27 \%$.

Hasil penelitian ini berbanding terbalik dengan penelitian yang dilakukan oleh (Syamsulastri 2017) hasil penelitian menunjukkan bahwa ada hubungan yang bermakna antara ketersediaan Fasilitas dengan kepatuhan perawat dalam melakukan hand hygiene dibuktikan dengan nilai uji statistik $p=$ value 0,010. Nilai PR 2,019 dengan nilai 95\% CI, proporsi fasilitas yang ada cenderung untuk responden dalam melakukan hand hygiene 2,019 atau 2 kali lipat lebih besar dibandingkan dengan proporsi fasilitsas yang tidak ada.

Hasil dari fasilitas yang disediakan meliputi masing-masing ruangan yang dilengkapi dengan sabun antimikroba dan kertas tissue dan alcohol hand rub. Namun tingkat kepatuhan melakukan 6 langkah cuci tangan masih rendah. Hasil penelitian ini bertentangan dengan hasil penelitian yang dilakukan oleh pitted menyatakan bahwa salah satu kendala dalam ketidak patuhan terhadap 6 langkah cuci tangan adalah sulitnya mengakses tempat cuci tangan atau persediaan alat lainya yang di gunakan untuk melakukan 6 langka cuci tangan, kemudahan mengakses persediaan alat-alat untuk melakukan 6 langkah tangan, bak cuci tangan, sabun atau alcohol jell adalah sangat penting untuk membuat kepatuhan menjadi optimal sesuai standar (Damanik, 2015).

Didukung dengan teori Notoatmodjo bahwa fasilitas hand hygiene (sarana dan prasarana) adalah segala sesuatu yang dapat digunakan untuk mencegah terjadinya penularan infeksi. Didukung oleh WHO bahwa untuk meningkatkan kepatuhan dalam melakukan hand 
hygiene diperlukan multidimensi strategi. Pendekatan tersebut meliputi perubahan sistem dengan menyediakan hand rub berbasis alkohol selain wastafel dan sabun antiseptik di setiap titik perawatan (Notoatmodjo, 2010).

\section{Hubungan antara supervisi kepala ruangan dengan kepatuhan perawat dalam melakukan 6 langkah cuci tangan di RSUD Labuang Baji Makassar}

Supervisi kepala ruangan dalam penelitian ini terbagi atas 2 kriteria yaitu dilakukan dan tidak dilakukan. Hasil penelitian dari seluruh sampel perawat yang diteliti yaitu sebanyak 41 perawat di RSUD Labuang Baji Makassar didapatkan bahwa yang dilakukan sebanyak 90,6\% dan masih terdapat $77,8 \%$ perawat yang tidak dilakukan namun patuh. Hal ini disebabkan tingkat pendidikan diketahui sebagian besar lulusan Ners maka tingkat pengetahuanya tinggi dan paham akan 6 langkah cuci tangan. Adapun supervisi kepala ruangan yang dilakukan namun kurang patuhnya tinggi hal ini dikarnakan pihak kepala ruangan tidak melakukan pengawasan langsung dalam melaksanakan kebersihan tangan perawat, dan rumah sakit tidak memberikan sanksi bagi perawat yang tidak melaksanakan kebersihan tangan. Seseorang akan patuh bila pengawasan menegur maka perilaku akan ditinggalkan, ketika pengawasan itu sudah mulai menurun maka kepatuhan perawat menurun pula. Beberapa dari kuesioner hanya lulusan D3 3 perawat hal ini menyebabkan pengetahuan kurang tentang 6 langkah cuci tangan.

Asumsi penelitian bahwa supervisi kepala ruangan hendaknya selalu memberikan informasi secara terus menerus tentang 6 langkah cuci tangan kepada bawahannya sedangkan supervisi yang kurang dilakukan memiliki tingkat kepatuhan yang tinggi pula karena sebagian besar responden paham akan 6 langkah cuci tangan tanpa adanya arahan dari supervisi. Supervisi sebaiknya dilakukan dengan metode pendekatan pengamatan, karena pengamatan langsung sering menimbulkan berbagai dampak negatif, misalnya rasa takut dan tidak senang.

Supervisi kepala ruangan merupakan salah satu proses atau sebagian dari fungsi pengawasan dan pengendalian. Supervisi sebagai suatu proses kemudahan sumber yang yang diperlukan untuk menyelesaikan suatu tugas yang berkaitan dengan perencanaan kegiatan dan informasi dari kepemimpinan dan mengevaluasi setiap kinerja perawat. Berdasarkan hasil penelitian analisa statistik dengan menggunakan uji chi square diperoleh nilai $\rho=0,229$. Dari hasil penelitian tersebut membuktikan bahwa tidak ada hubungan yang bermakna antara supervisi kepala ruangan dengan kepatuhan perawat dalam melakukan 6 langkah cuci tangan di RSUD Labuang Baji Makassar.

Penelitian ini juga sejalan dengan hasil penelitian (Hutahaean, 2018) yang menjelaskan bahwa peran dan fungsi kepala ruangan berpengaruh terhadap kepatuhan perawat dalam pencegahan dan pengendalian infeksi. Hal ini diperkuat dalam penelitian Arifianto di ruang Bougenvile RSUD Dr. Soedirman Kebumen Tahun 2017 menunjukkan ada hubungan antara supervisi kepala ruangan dengan kepatuhan hand shygiene 5 moment dengan nilai $p=v a l u e ~ 0,843$ (Arifianto, 2017). Sejalan dengan penelitian yang dilakukan oleh Tahir menunjukan bahwa ada hubungan yang bermakna antara supervisi dengan kepatuhan perawat dalam melaksanakan hand hygiene di Rumah Sakit Universitas Hasanuddin Tahun 2016 dengan nilai p-value 0,87 (Tahir, 2016). Penelitian ini juga didukung oleh penelitian Fina di ruangan rawat inap RSUD dr. Rasidin Padang Tahun 2015 terdapat hubungan yang bermakna antara supervisi dengan kepatuhan perawat pelaksana melaksanakan hand hygiene dengan nilai $p=v a l u e ~ 0,38$ (Fina, 2015). Supervisi merupakan pemberi bantuan, bimbingan/pengajaran, dukungan pada perawat dalam melakukan hand hygiene sesuai kebijakan dan prosedur. Supervisi perlu dilakukan secara berkesinambungan yang pada akhirnya dapat meningkatkan pengetahuan dan kepatuhan perawat dalam melakukan hand hygiene.

Didukung dengan teori Suarli yang menyatakan bahwa supervisi yang dilakukan kepala ruangan harus dilakukan secara objektif yang bertujuan untuk pembinaan. Pelaksanaan supervisi bukan hanya untuk mengawasi apakah perawat melakukan hand hygiene dengan baik dan benar sesuai dengan kebijakan dan prosedur suervisi juga melakukan pengamatan secra langsung dan berkala untuk kemudian bila ditemukan masalah segera diberikan bantuan yang bersifat langsung 
(Suarli dkk., 2015). Pendapat ini sejalan dengan Nursalam yang manyatakan bahwa dalam melakukan supervisi yang tepat, supervisor harus dapat kapan dan apa yang harus dilakukan supervisi (Nursalam, 2016).

\section{SIMPULAN}

Berdasarkan hasil penelitian yang dilakukan RSUD Labuang Baji Makassar, maka dapat ditarik kesimpulan bahwa : Ada hubungan antara motivasi dengan kepatuhan perawat dalam melakukan 6 langkah cuci tangan, Tidak ada hubungan antara fasilitas dengan kepatuhan perawat dalam melakukan 6 langkah cuci tangan, Tidak ada hubungan antara supervisi kepala ruangan dengan kepatuhan perawat dalam melakukan 6 langkah cuci tangan.

\section{SARAN}

Perlu adanya suatu program pendidikan tentang 6 langkah cuci tangan yang berkelanjutan dengan informasi yang selalu diperbarui, Perlu adanya prosedur kerjasama dan persamaan persepsi terhadap pentingnya 6 langkah cuci tangan yang dapat mengurangi infeksi nosokomial di Rumah Sakit dan Diharapkan peneliti selanjutnya dapat mengkaji faktor lain yang berhubungan dengan kepatuhan 6 langkah cuci tangan, serta membuat pelatihan yang tepat untuk meningkatkan kepatuhan perawat.

\section{DAFTAR PUSTAKA}

Andriani, M. (2017). Hubungan Supervisi Kepala Ruangan Dengan Pendokumentasian Asuhan Keperawatan Di Ruangan Rawat Inap RSI Ibnu Sina Bukittinggi. Jurnal Ilmu Kesehatan 'Afiyah, 4, 18-24.

Boyce, J. M. (2013) 'Update on hand hygiene', American Journal of Infection Control, 41(5 SUPPL.). doi: 10.1016/j.ajic.2012.11.008.

CDC (2016) 'National and Infections, Healthcare Associated Report., Progress'. Available at: https://www.cdc.gov/HAI/pdfs/progress-report/hai-progress-report.pdf.

Damanik, S. M., Susilaningsih, F. S., \& Amrullah, A. A. (2012). Kepatuhan Hand Hygiene Di Rumah Sakit Immanuel Bandung. Student E-Journals, 1, 1-14.

Darmadi D. (2014) Infeksi Nosokomial Problematika dan Penanganannya. Jakarta: Salemba Medika.

Desiyanto, F. A. and Djannah, S. N. (2016) 'efektivitas mencuci tangan menggunakan cairan pembersih tangan antiseptik (hand sanitizer) terhadap jumlah angka kuman', Jurnal Kesehatan Masyarakat (Journal of Public Health), 7(2). doi: 10.12928/kesmas.v7i2.1041.

Ernawati, E. et al. (2014) 'Penerapan Hand Hygiene Perawat di Ruang Rawat Inap Rumah Sakit Application of Nurse ' s Hand Hygiene in Hospital 's Inpatient units', 28(1), pp. 89-94.

Fauzia, N., Ansyori, A. and Hariyanto, T. (2017) 'Kepatuhan Standar Prosedur Operasional Hand Hygiene pada Perawat di Ruang Rawat Inap Rumah Sakit', Jurnal Kedokteran Brawijaya, 28(1), pp. 95-98. doi: 10.21776/ub.jkb.2014.028.01.31.

Ferdinah, R. (2017) 'Gambaran Perilaku Hand Hygiene dan Determinannya pada Perawat di Ruang Rawat Inap Gedung X Rumah Sakit. Jakarta', Universitas Nusantara PGRI Kediri, 1, pp.17.Availableat: http://repository.uinjkt.ac.id/dspace/bitstream/123456789/36710/1/RAHFITA 


\section{FERDINAH-FKIK.pdf.}

Fitria Donosepoetro, I., Hakim, L. and Hariyanto, T. (2018) 'Surveilans Infeksi Nosokomial di RSJ Dr. Radjiman Wediodiningrat Lawang, Aplikasi Kriteria McGeer', Jurnal Kedokteran Brawijaya, 29(4), pp. 353-357. doi: 10.21776/ub.jkb.2017.029.04.12.

Hand Hygiene Australia (2016) Five Moments of Hand Hygiene, Hand Hygiene Australia.

Hidayat, A. A. (2014). Metode Penelitian Keperawatan dan Teknik Analisa Data (1st ed.). Jakarta: Salemba Medika.

Hutahaean.S., Anggraini.N.V., Nababan.D., Analysis of Factors Related to the Head of Nurses in the Implementation of Prevention and Control of Infections in Hospital. JMMR (Jurnal Medicoeticolegal dan Manajemen Rumah Sakit), 8 (3): 158-162, December 2019. http://journal.umy.ac.id/index.php/mrs. https:// doi.org/10.18196/jmmr.83102

Hutahaean.S., Handiyani.H., Gayatri.D., Pelaksanaan Pencegahan Dan Pengendalian Infeksi Melalui Penguatan Peran Dan Fungsi Kepala Ruang Di Rumah Sakit. Jurnal Akademi Keperawatan Husada Karya Jaya, Volume 4, Nomor 1, Maret 2018 ISSN 2442-501X. http://ejurnal.husadakaryajaya.ac.id/index.php/JAKHKJ/article/viewFile/72/65

Kambuaya, P. R., Kumaat, L. T., \& Onibala, F. (2016). Hubungan Beban Kerja Perawat Dengan Waktu Tanggap Pelayanan Keperawatan Gawat Darurat Menurut Persepsi Pasien Di IGD RSUD Kabupaten Sorong. e-Journal Keperawatan (e-Kp), IV(1).

Kasim, Y., Mulyadi, \& Kallo, V. (2017). Hubungan Motivasi dan Supervisi Dengan Kepatuhan Perawat Dalam Penggunaan Alat Pelindung Diri (APD) Pada Pasien Gangguan Muskuloskeletal Di IGD Prof. Dr. R. D. Kandou Manado. e-Journal Keperawatan (e-Kp), V(1).

Kwok, Y. L. A., Callard, M. and McLaws, M. L. (2015) 'An automated hand hygiene training system improves hand hygiene technique but not compliance', American Journal of Infection Control, 43(8), pp. 821-825. doi: 10.1016/j.ajic.2015.04.201.

Malik, R. H. A., Puspitasari, N. and Tarigan, M. (2012) 'MEDAN', GAMBARAN CUCI TANGAN PERAWAT DI RUANG RA, RB, ICU,CVCU, RSUP. H. ADAM MALIK MEDAN.

Notoatmodjo, S. (2010). Metodologi Penelitian Kesehatan. Jakarta: Rineka Cipta.

Notoatmodjo, S. (2012). Ilmu Prilaku Kesehatan. Jakarta: Rineka Cipta.

Notoatmodjo, S. (2012). Promosi Kesehatan Teori dan Aplikasi. Jakarta: Rineka Cipta.

Nursalam. (2016). Manajemen Keperawatan: Aplikasi dalam Praktik Keperawatan Profesional (3rd ed.). Jakarta: Salemba Medika.

Putri Wulandini S, Roza, A. (2016) 'PERILAKU PERAWAT DALAM PENGGUNAAN ALAT PELINDUNG DIRI (APD) DI IRNA MEDIKAL RSUD PEKANBARU 2016', Analis Kesehatan, pp. 1-9.

Rejeki, R. L. (2017, Februari). Faktor-Faktor Yang Berhubungan Dengan Kinerja Perawat Pelaksana Dalam Pencegahan Dan Pengendalian Infeksi Rumah Sakit Di Rumah Sakit Islam Ibnu Sina Simpang 
Empat. Retrieved April 5, 2018, from http://scholar.unand.ac.id

Sarma Eko Natalia Sinaga (2016) 'Kepatuhan Hand Hygiene Di Rumah Sakit Misi Rangkasbitung', Students e-Journal. Available at: http://jurnal.unpad.ac.id/ejournal/article/view/683.

Septiari, B. B. (2012) ‘No Title', Infeksi Nosokomial (1st ed.). Yogyakarta: Nuha Medika.

Sinaga, S. E. (2016). Kepatuhan Hand Hygiene Di Rumah Sakit Misi Rangkasbitung. Ejournal Stikes Borromeus, 7-12.

Sitepu, A. T. (2013). Beban Kerja dan Motivasi Pengaruhnya Terhadap Kinerja Karyawan Pada PT. Bank Tabungan Negara Tbk Cabang Manado. Jurnal EMBA, I(4), 1123-1133.

Tini Ariyati, Raharjo Apriyatmoko, H. H. P. (2016) 'hubungan karakteristik perawat dengan kepatuhan penerapan prosedur keselamatan pasien di instalasi rawat inap ii rsj prof. dr.Soerojo Magelang', anzdoc.Availableat:file http:///C:/Users/URINDO/Downloads/anzdoc.com_hubungan karakteristikperawat-dengan-kepatuhan-pe.pdf.

Umboh, F. J., Doda, D. V., \& Kandou, G. D. (2017). Analisis Faktor-Faktor Yang Berhubungan Dengan Kepatuhan Perawat Melaksanakan Hand Hygiene Dalam Mencegah Infeksi Nosokomial Di Ruang Rawat Inap Rumah Sakit Advent Manado. Paradigma, 5.

Wahyudi, M. N. (2015, November 18). Pola Hidup Sehat Dalam Perspektif Al-Qur'an. Retrieved April 192018 from http:/ / eprints.walisongo.ac.id

WHO (2016) 'Assessing the Burden of Healthcare-Associated Infections through Prevalence Studies: What Is the Best Method?', Infection Control \& Hospital Epidemiology, 35(6), pp. 674684. doi: $10.1086 / 676424$.

WHO (2017) 'Penerapan Kewaspadaan Standar di fasilitas pelayanan kesehatan', AIDE-Memoire:World Health Organization, pp. 1-2. Available.at: http://www.who.int/csr/resources/publications/AMStandardPrecautions_bahasa.pdf ?ua=1. 
